CHAPTER TWO

\title{
THE GATHERINGS OF CHRISTIANS IN THE MORNING
}

\section{INTRODUCTION}

In the first chapter it has been argued that in the thirties and forties of the first century Christians began to hold communal suppers once a week, namely on Sunday evening. From the beginning of the second century Christians began to come together more frequently. In addition to their gatherings on Sunday evening, they began to meet early in the morning, first on one day, later on more days of the week. This chapter will examine first the origin of the early morning gathering and then the development of the morning gatherings in the second and third centuries.

\section{The origin of the Christian gathering In the MORNING}

During the first century Christians held their communal gatherings on Sunday evening. From the beginning of the second century at the latest, Christians felt the need to hold more meetings. Alongside the supper held on Sunday evening, a cultic assembly began to be held early in the morning before dawn, probably also on Sunday. The earliest evidence for Christian gatherings early in the morning comes from Pliny the Younger, who was the Roman governor of Bithynia-Pontus in $c a .110-112$ CE. In a letter to Trajan, Pliny asks the Emperor how to deal with Christians who were denounced to him. Pliny had interrogated some apostate Christians and this is what he had learned about their practices:

They declared that the sum total of their guilt or error amounted to no more than this: they had met regularly before dawn on a fixed day to chant verses alternately among themselves in honour of Christ as if to a god, and also to bind themselves by oath (sacramentum), not for any criminal purpose, but to abstain from theft, robbery and adultery, to commit no breach of trust and not to deny a deposit when called upon to restore it. After this ceremony it had been their custom to disperse and reassemble later to take food of an ordinary, harmless kind; but they 
had in fact given up this practice since my edict, issued on your instructions, which banned all political societies (hetaeriae). ${ }^{1}$

Since these Christians declared that, on the day on which they assembled before dawn, they were in the habit of reconvening in order to have their common supper, the "fixed day" on which the morning gathering took place was almost certainly the Sunday.

Scholarly opinions are divided with respect to the character of the morning gathering mentioned by Pliny. According to one interpretation, the morning meeting of Christians described by Pliny was a kind of "business meeting" during which the members of the Christian community settled their internal conflicts, just as other people did in their Greek and Roman clubs. ${ }^{2}$ This interpretation is based on a juridical understanding of the term sacramentum (solemn engagement). However, Pliny's account of the meeting suggests that it had a religious rather than businesslike, forensic or juridical character. Moreover, it is improbable that in order to settle quarrels within their community Christians met before dawn. Since they had to go to work at daybreak, this timing of their meeting would put their dealings under an inconvenient time pressure.

According to another interpretation, the morning gathering in question was a "service of the Word," consisting of Scripture readings, a sermon and prayer, and was concluded (as a result of Pliny's edict) by a eucharistic celebration. This interpretation would imply that, until Pliny took his measures against Christians, the evening meeting consisted of the Eucharist and an agape meal. As a consequence of Pliny's ban on associations, the Christians in Bithynia and Pontus abandoned the agape meal in the evening and transferred the Eucharist to their "service of the Word" at dawn. ${ }^{3}$ However, this interpretation must be considered highly improbable. There is no indication that in the early second century Eucharist and agape were distinct rites. In the first and second centuries, up to and including Tertullian's days, the weekly communal supper of Christian communities, that is, the Eucharist, and the agape meal were one and the same event, taking place in the

Plin., Ep. 10.96.7 (tra. Betty Radice).

2 Dennis Smith, From Symposium to Eucharist, 202-203.

3 A.N. Sherwin-White, The Letters of Pliny. A Historical and Social Commentary (Oxford: Clarendon Press, 1966), 704-708; Jörg Salzmann, "Pliny (ep. 10,96) and Christian Liturgy-A Reconsideration,” SP 20 (1989), 389-395, esp. 394-395. 
evening. ${ }^{4}$ More importantly, there is no sign whatsoever in Pliny's account that the meeting before dawn comprised the celebration of the Eucharist. Pliny may be correct in stating that some former Christians, now apostates, had ceased to attend the Sunday evening meetings of their congregations. However, there is no ground for the supposition that, as a consequence of Pliny's ban on associations, these Christian congregations discontinued the celebration of the Eucharist on Sunday evening and moved it to the Sunday morning. It cannot be argued that the meeting at dawn comprised a Eucharist just on the grounds that the Eucharist in the evening had been discontinued, for there is no reason to believe that it had been discontinued in the evening. It had only been abandoned by those who later became apostates, at least according to their declaration given to Pliny.

Still another interpretation sees the Christian gathering in the morning described by Pliny as a Christian counterpart of the Jewish gathering in the synagogue on Sabbath. ${ }^{5}$ It is highly implausible, though, that Christians initiated morning gatherings using the analogy of the meetings of Jews in the synagogue on the Sabbath. The Christian and the Jewish meeting were of an entirely different character. First, an important element of the Christian ceremony was the antiphonal singing of hymns of praise. The accounts of meetings in the synagogue on the Sabbath, on the other hand, make no mention of any singing whatsoever. Second, the main objective of the synagogal meetings on the Sabbath was the reading and discussion of the Law. However, the Christian meetings mentioned by Pliny did not include the reading or discussion of any text. Third, in the synagogal meeting on the Sabbath, the participants quietly took their time, sometimes "till about the late afternoon"6 or "until the evening" or at

${ }^{4}$ The separation between Eucharist and agape becomes only visible in the third century, in the Trad. ap. and Cyprian. One should beware of projecting this separation back into the second century. This has now rightly been seen by Andrew McGowan, "Rethinking Agape and Eucharist in Early North African Christianity," SL 34 (2004), 165-176, esp. 166, and Paul Bradshaw, Eucharistic Origins (Oxford: Oxford University Press, 2004), 29-30, 99.

${ }^{5}$ Graham N. Stanton, "Aspects of Early Christian and Jewish Worship: Pliny and the Kerygma Petrou," in Worship, Theology and Ministry in the Early Church. Essays in Honor of Ralph P. Martin (Sheffield: JSOT Press, 1992), 84-98, esp. 85-93.

${ }^{6}$ Philo, Hyp., apud Euseb., Praep. ev. 8.7.12-13.

7 Jos., Ap. 1.210 . 
least until noon. ${ }^{8}$ They were in no particular hurry. ${ }^{9}$ Christians, on the other hand, had to meet before dawn because the Sunday was a working day; they must have held their morning ceremony under a certain amount of time pressure.

Finally, there are interpretations of Pliny's letter that assume that in his account of the Christian practices he is misrepresenting what his informants had told him. These former Christians would have explained to Pliny that before being baptized as Christians they had made the promise to forsake all forms of evil behaviour. Pliny would then have thought that Christians made this promise every Sunday. ${ }^{10}$ But why would the persons whom Pliny interrogated about the activities in their weekly gathering before sunrise, have spoken about their baptism? And why would they have spoken of a vow (sacramentum) and not of the ritual of immersion?

According to still another interpretation, Pliny's informants would have described a "service of the Word," consisting of a reading and a sermon. Trying to plead not guilty, they would have stressed the severity of the moral admonitions contained in the sermon so strongly that Pliny had concluded that they had pledged every Sunday to refrain from all evil. ${ }^{11}$

It is obviously true that Pliny's account of the Christian morning services may distort or misrepresent the report he had received from his informants, either because he misunderstood their information, or because he adapted it consciously or unconsciously to his or Trajan's frame of reference. However, this view of Pliny's report is liable to lead to uncontrollable speculation. In fact, Pliny says nothing about baptism, reading of any Scriptures, or a homily. There is little point in replacing Pliny's account by a hypothetical construct consisting of elements (e.g., reading, homily) that Pliny does not mention. It seems methodically more sensible to take Pliny's words more seriously and to assume that he really wanted to say that on a fixed day of the week

8 Jos., Vit. 279.

9 Philo, Som. 2.127.

10 Jörg Salzmann "Pliny (ep. 10,96) and Christian Liturgy-A Reconsideration," SP 20 (1989), 393-394. He suggests that the apostate Christians told Pliny about a "service of the Word" (reading and homily), tried to plead not guilty and thus stressed the moral exhortations of the Sunday morning sermons.

11 Paul Bradshaw, Daily Prayer in the Early Church (London: Alcuin/SPCK, 1981), 43. 
Christians in Bithynia met before sunrise, sang hymns to Christ, and took a vow to abstain from evil. There is no reason to assume that the gathering comprised a Eucharist. Whether it took place in some room of a house or in the open, is a moot question.

Whatever the precise content of the Christian morning service in Bithynia may have been, this ceremony is the earliest traceable stage of the Church's tradition of worshipping on a Sunday morning.

In view of the fact that the Christians traditionally gathered (and continued to gather) in the evening for their common supper, the question must be asked as to why the Bithynian Christians initiated meetings in the early morning next to those in the evening. Since the letter of Pliny does not contain an answer to this question, let us ask if there are historical analogies which may explain why the Bithynian Christians began to hold meetings before sunrise.

In the Graeco-Roman world religious meetings at dawn were held by various pagan and Jewish groups. According to Josephus, the Essenes in Judea and elsewhere in Palestine assembled before sunrise and "offered to Him [the Sun] ${ }^{12}$ some traditional prayers as if beseeching him to appear." 13 After this the Essenes went to their work and in the evening they reassembled for supper. ${ }^{14}$ Thus, the Christians of Bithynia and the Essenes had more or less the same schedule for the day (worship before sunrise, daily work, ${ }^{15}$ common supper), with the only significant differences being that the Essenes performed this programme every day of the week, rather than once a week on a Sunday, as was the Bithynian Christians' practice. The Essenes also had a common meal at noon.

Another example of communal worship before sunrise is the finale of the Pannychis celebrated by the Therapeutae near Alexandria. Philo relates that at the end of the night during which they celebrated this festival, that is, at dawn,

${ }_{12}$ Whether the Essenes really prayed to the Sun, as Josephus claims, or to God, addressing the Sun only as an image of God, is a much-debated question. The former seems more probable, as has been argued on good grounds by T.M. Jonquière, Prayer in Josephus (Leiden: Brill, 2007), 54-55.

${ }_{13}$ Jos., BJ 2.128-129.

${ }^{14}$ Jos., BJ 2.132.

15 Except that the Essenes did not work on the Sabbath. 
they stand with their faces and whole body turned to the east and when they see the sun rising they stretch their hands up to heaven and pray for bright days and knowledge of the truth and the power of keen sighted thinking. And after the prayers they depart each to his private sanctuary. ${ }^{16}$

This morning prayer, however, is the communal variant of the morning prayer which each of the Therapeutae prayed individually every morning at sunrise. ${ }^{17}$

One of the manuscripts from Qumran, 4Q503, contains the texts of prayers for each day of the month. ${ }^{18}$ The composition of the text is dated to the first century BCE. Since the persons who were supposed to use these prayers refer to themselves in the first person plural ("our deliverance," "we, his holy people," "for us," "our joy," etc.), the prayers seem to be meant as community prayers. A number of them had to be said "at the rising of the sun"; the manuscript has been preserved only in fragments, but there is the possibility that it once contained prayers for each day of a particular month. It remains unclear as to whether the cycle of this month started anew each month or only once a year.

The Christians of Bithynia met weekly for morning prayer, in contradistinction to several Jewish groups: the Essenes met daily, the Therapeutae yearly at the end of their Pannychis, and the group behind 4Q503 daily, either during a certain month of the year or during the whole year. The cycle of the Christian worship at sunrise in Bithynia thus differs clearly from that of the Jewish groups mentioned. However, the importance of the testimonies adduced so far is that they show how Jews gathered communally and prayed to God at sunrise. Many other groups in the Mediterranean region did the same, as we shall see presently.

Prayer or singing at sunrise facing the east, either daily or less frequently, was also a widely spread phenomenon among non-Jews in the

${ }^{16}$ Philo, Contempl. 89 (tra. F.H. Colson).

${ }_{17}$ Philo, Contempl. 27. For daily prayers before sunrise or in the morning, see also Ber. 1.2 and 1.4, but these are individual prayers.

${ }_{18}$ F. García Martínez and E.J. Tigchelaar, The Dead Sea Scrolls Study Edition, vol. 1 (Leiden: Brill, 1997-1998), 999-1009. 
Graeco-Roman world. ${ }^{19}$ Pagans could pray to their gods individually ${ }^{20}$ or communally in or outside their temples and shrines. ${ }^{21}$

The evidence for worship of the gods at dawn among pagans includes the following indications and allusions. Not all of these concern historically established practices, but they all prove that worship at dawn, including prayer and singing, was a well-known concept in the Graeco-Roman world: many people would be acquainted with it and few would be surprised if they came in contact with it.

(1) A Greek inscription from Teos from the beginning of the Roman imperial time prescribes that a hymn should be sung every morning at the opening of the Temple of Dionysus. ${ }^{22}$

(2) According to Apuleius, midway through the second century, "a choir saluted the breaking day with the loud hymn that they always sang at the hour of prime" in the Isis temple at Corinth. ${ }^{23}$

(3) During a visit to Smyrna about $170 \mathrm{CE}$, Aelius Aristides dreamed that in the Temple of Asclepius he heard the temple servants sing an old hymn to Zeus at dawn: "I praise Zeus, the highest of all." ${ }^{24}$ On

${ }^{19}$ For an intriguing and most instructive visualisation of this practice, see the painting "Pythagoreans celebrate sunrise" by the Russian artist Fyodor Bronnikov (1869), now in the State Tretyakov Gallery, Moscow. See Masterpieces of Russian Art. Шедевры русской нсивописи, руководитель проекта Андрей Астахов (Москва: Беый город, 2006), 284-285 and Appendix IV below. That Neo-Pythagoreans adored the sun at sunrise was a 19th-century theory, advocated among others by E. Zeller in his influential Die Philosophie der Griechen, 3 vols. (Tübingen: Fues, 1844-1852), vol. 3 , section 2 (1852), 583, 591. The theory was based on scanty indications, mainly Diog. Laert. 8.17 and Philostr., Vita Apol. 6.10. It has convincingly been confuted by J.B. Lightfoot, "On Some Points Connected with the Essenes," in his Saint Paul's Epistles to the Colossians and to Philemon, 5ed. ed. (London: Macmillan, 1875; 1880), 380-382, 387.

${ }^{20}$ Cf. Virgil, Aeneid 8.68, where Aeneas prays at sunrise facing the east; and Philostr., Vita Apol. 6.10, where Philostratus states that the Neo-Pythagorean philosopher Apollonius of Tyana, in Cappadocia, in the first century CE, was used to pray at dawn to the sun.

${ }^{21}$ Corpus Inscriptionum Graecarum III, 1-2, n. 171 (Berlin: Reimer, 1878) = II ${ }^{2}$ III, $1-2$, n. 4533 (Berlin: de Gruyter, 1935) is an example of communal morning prayer to Asclepius, Hygieia and Telesphorus (2nd century CE). For the date of the inscription see Édouard des Places, La religion grecque (Paris: Picard, 1969), 168; J. Quasten, Musik und Gesang in den Kulten der heidnischen Antike und christlichen Frühzeit (Münster: Aschendorff, 1973), 65. Quasten deals with prayer during the liturgy of an Isis cult association.

${ }^{22}$ Louis Robert, Études anatoliennes: recherches sur les inscriptions grecques de l'Asie mineure (Paris: De Boccard, 1937), 18-21.

${ }^{23}$ Apul., Met. 11.20 (tra. R. Graves, p. 238).

24 Aelius Aristides, Sacred Tales 1.30. For other examples of pagan singing in the morning see Martin P. Nilsson, "Pagan Divine Service in Late Antiquity," HTR 38 (1945), 63-69, esp. 66-68. 
another occasion he dreamed that at sunrise, a crowd in the marketplace of Smyrna recited the prayer "O Sun, turning round the flame by swift horses." ${ }^{25}$

(4) Lucian in his satire On Dances (or On Pantomime) claims that the Indians venerated the sun at the beginning of every day, not by saying prayers but by dancing: "The Indians, when they rise to offer their morning salutation to the Sun, turn to the east and silently greet the God with movements that are designed to represent his own course through the heavens."26

(5) In his Metamorphoses, Apuleius mentions an Egyptian prophet who, in the company of others, prays to the sun facing the east. ${ }^{27}$

(6) The fact that certain pagan groups offered prayers at sunrise was not unknown among the Christians, at least from Tertullian onwards. Already in 197 CE he wrote:

[Some pagans] imagine that the sun is the Christian god. They have observed that when we pray, we face to the east and we rejoice on the day of the sun. Do you do anything less than this? Do you not sometimes cause your lips to quiver toward the rising sun as an act of adoration? ${ }^{28}$

What Tertullian knew about pagans praying at sunrise at the end of the second century, the Bithynian Christians may have known at the beginning of that century.

(7) The assiduity with which gentiles used to assemble early in the morning to worship their gods is even held up as an example to Christians by the Apostolic Constitutions:

The Gentiles every day, when they arise from sleep, run to their idols to worship them, and before all their work and all their labours do first of all pray to them.... If, therefore, those who are not saved frequently assemble together for such purposes as do not profit them, what apology will you make to the Lord God, you who forsake His Church, not imitating so much the heathen, but by your absence grow slothful, or turn apostate, or act wickedness? ${ }^{29}$

${ }^{25}$ Aelius Aristides, Sacred Tales 1.22. The prayer quoted comes from Euripides, Phoenissae 3.

${ }^{26}$ Luc., Dances 17 (tra. H.W. and F.G. Fowler).

27 Apul., Met. 2.28.

${ }^{28}$ Tert., Nat. 1.13 (tra. Q. Howe in ANF). Cf. Apol. 16.11: "Many of you with an affectation of sometimes worshipping heavenly bodies move your lips towards the rising sun" (tra. T.R. Glover in LCL).

${ }^{29}$ Const. ap. 2.60 (tra. James Donaldson, adapted). 
(8) A geographically close analogy to the Christian worship at dawn in Bithynia is the morning prayer of a private association at Oinoanda in Lycia, attested by the inscription SEG 933 (3rd century CE). ${ }^{30}$ The prayer is addressed to a deity "dwelling in fire," "Aither," identified with Theos Hypsistos and Helios. The inscription invites its readers "to pray looking to him at dawn, as you look towards the east." ${ }^{31}$

(9) The rites of another group of worshippers of Theos Hypsistos, the pagan Messalians, are described by Epiphanius. He seems to locate them somewhere in Syria, perhaps in the second or third century CE. This is, among other things, what he has to say about their gatherings:

They would gather in the evening and at dawn with much lighting of lamps and torches and lengthy singing of hymns and acclamations to God by the zealous among them, through which hymns and acclamations they fondly think to conciliate God. ${ }^{32}$

The above evidence from Jewish, pagan, and Christian sources shows that coming together in the early morning for worship was a widespread phenomenon in the Graeco-Roman world. For Christians in Asia Minor about $100 \mathrm{CE}$, the idea of assembling by sunrise for worship was not something very difficult to conceive, therefore. They could simply follow the analogy of many other religious groups and associations.

Why the Christians in Bithynia placed their morning service on Sunday remains a matter for conjecture. The fact that they placed it on the day of their communal supper may be an indication that the morning gathering served as a kind of preparation for the evening gathering. By taking the vows of perfect honesty, fidelity and trustworthiness in the morning they may have intended to attain the ceremonial purity which enabled them to participate freely in the Eucharist later that day. Another reason may have been that Christians longed so much for the joy of their weekly meeting on Sunday that they could

${ }^{30}$ S. Mitchell, "The Cult of Theos Hypsistos between Pagans, Jews, and Christians," in Pagan Monotheism in Late Antiquity, eds. P. Athanassiadi and M. Frede (Oxford: Clarendon Press, 1999), 81-148, esp. 86-108.

${ }^{31}$ See G.H.R. Horsley, "Answer from an Oracle," in New Documents Illustrating Early Christianity, vol. 2 (North Ryde, Australia: The Ancient History Documentary Research Centre, Macquarie University, 1982), 37-44, esp. 39.

${ }^{32}$ Epiph., Panar. 80.2. See S. Mitchell, "The Cult of Theos Hypsistos," 92-93; Frank Williams (tra.), The Panarion of Epiphanius of Salamis, Books II and III (Leiden: Brill, 1994), 629-630. 
not wait until the supper and anticipated that festive event by gathering already at the beginning of the day. ${ }^{33}$ They may also have wished to pay respect to Christ before coming to the meal where he was their host and they his guests. Finally, the accounts of Jesus' resurrection on Sunday before dawn may also have played a part in their decision to gather on Sunday morning; after all, the Sunday was now beginning to be regarded as the day of Jesus' resurrection, as noted for the first time by Ignatius. ${ }^{34}$

From the beginning of the second century, Christians began to hold more morning meetings during the week, not only on Sunday morning, but also on other mornings. This proliferation of meetings is evidenced by Ignatius, the Didache, Barnabas, 2 Clement and other authors. ${ }^{35}$

The reason for this innovation probably was that there were several other religious groups, both Jewish and pagan, which met on a daily basis. This applies, for instance, to the Essenes, as we have seen above, and to the Isis cult in Corinth in the middle of the second century. ${ }^{36}$ The inscription from Teos mentioned above, which prescribes the singing of a hymn to Dionysus, also stipulates that it should be sung every day at the opening of the temple.

The increase of the number of Christian meetings in the morning, on Sunday as well as on other days, may have been furthered by the changing position of the leaders of congregations. In the second century the sedentary clergy were increasingly supported by their congregations; they no longer needed to practise a trade to earn a living. Supporting clergy with food and money probably began as early as the first century ${ }^{37}$ and became more common in the second century. The Didache, for instance, urges Christians to provide food for prophets and teachers who settle in a community in order to serve it; in this way the ministers were exempted from the necessity to earn their cost of living by doing other work. ${ }^{38}$ The ministry of the prophets and teachers could also be taken over by appointed overseers (bishops) and ser-

\footnotetext{
${ }^{33}$ See A.B. du Toit, Der Aspect der Freude im urchristlichen Abendmahl (Winterthur: Keller, 1965), esp. 116-118.

34 Ign., Magn. 9.1-2.

${ }^{35}$ The testimony of these authors will be discussed below.

${ }^{36}$ Apul., Met. 11.20.

${ }^{37}$ Gal. 6:6; 1 Tim. 5:17-18.

${ }^{38}$ Did. 13.1-7.
} 
vants (deacons). According to the Didache, these latter officials must not be despised; this probably means that they could also look to the congregation for material support. ${ }^{39}$

Once Church officials were supported by their congregations they were in a position to arrange more meetings a week. Many of them did so, not only to build up, strengthen and reinforce their congregation, but possibly also to meet the needs and wishes of members of their congregation. Several second-century Christian authors urge their addressees to gather more frequently. From the contexts in which these admonitions appear, it is clear that the main reason why these authors urged Christians to meet more often was that they regarded more frequent meetings as a means to strengthen the Christians' faith and to prevent them from sliding into laxity, their former religion or "heresy." Thus the concern for the believers' "orthodoxy" may have been another reason for the clergy to increase the number of gatherings.

One of the authors who urge Christians to come together more often is Ignatius in his letter to the Ephesians: "Be eager, therefore, to come together more frequently ( $\pi v \kappa v o ́ \tau \varepsilon \rho o v)$ to give thanks and glory to God. For when you frequently ( $\pi \nu \kappa \nu \hat{\omega} \varsigma$ ) gather as a congregation, the powers of Satan are destroyed...."40 A similar admonition occurs in his letter to Polycarp when he states that Christian assemblies should be held more frequently ( $\pi v \kappa v o ́ \tau \varepsilon \rho o v) .{ }^{41}$ These admonitions mean that Ignatius wanted his hearers to hold more meetings in a given space of time than they already did, that is, more than once a week. By using $\pi \cup \kappa v o ́ \tau \varepsilon \rho o v$ in his letters to the Ephesians and Polycarp, Ignatius did not mean to say that Christians should not miss the weekly gatherings or should come together "more tightly," that is, in greater numbers. ${ }^{42}$ He means that Christians should gather more frequently than once a week, as Bart Ehrman has indicated correctly in his translation: "Let

${ }^{39}$ Did. 15.1-2.

${ }^{40}$ Ign., Eph. 13.1 (tra. Bart Ehrman).

${ }^{41}$ Ign., Pol. 4.2.

${ }^{42}$ As suggested by Th. Zahn, Ignatius von Antiochien (Gotha: Perthes, 1873), 345, note 1; William R. Schoedel, Ignatius of Antioch (Philadelphia: Fortress Press, 1985), 74, note 1; Taras Khomych, "The Notion of puknôs as a Distinctive Characteristic of Liturgical Celebrations in the Letters of St Ignatius of Antioch," SP 40 (2006), 441-

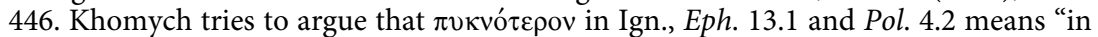
concord," "in peace," but his argumentation does not carry conviction: the leap from "tightly" to "in concord" is too far. 
there be more frequent gatherings." ${ }^{33}$ The admonition to have more frequent meetings with a Church's officers was also meant to prevent people from going to unauthorized meetings held by competing false teachers and prophets. ${ }^{44}$

The Didache also admonishes its addressees to come together frequently, that is, more often than only for the meeting on Sunday, as was standard practice (Did. 14.1): "Gather together frequently ( $\pi \nu \kappa v \hat{\omega} \varsigma$ ), seeking the things that benefit your souls, for all the time you have believed will be of no use to you if you are not found perfect in the last time." ${ }^{45}$ The context of this passage shows the author's anxiety for his readers to attain perfection in their Christian life, prepare themselves for the end of times and the Day of Judgement, and guard themselves against false teachers. In order to protect themselves from all kinds of danger and to be saved on the Last Day, Christians would do well to gather more frequently.

The same idea is expressed by the author of 2 Clement:

Let us think about paying attention and believing not only now, while we are being admonished by the elders, but also when we have returned home, let us remember the Lord's commands and not allow ourselves to be dragged off the other way by worldly desires, but let us come here

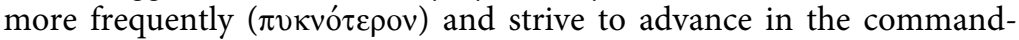
ments of the Lord, in order that all of us, being of one mind, may be gathered together into life. ${ }^{46}$

The passages just quoted from Ignatius, the Didache and 2 Clement suggest that in the beginning of the second century the number of weekly gatherings increased from one, on Sunday evening, to more, namely on Sunday morning and on other days of the week. The author of the Epistle of Barnabas goes so far as to urge his audience "to seek the faces of the saints daily." ${ }^{47}$ This is arguably the earliest evidence for

${ }^{43}$ Ign., Pol. 4.2 (tra. Bart Ehrman). See also J.B. Lightfoot, The Apostolic Fathers, Part II, vol. 2 (London: Macmillan, 1989), 66. He argues that Ignatius means that Christians should meet more frequently.

${ }^{44}$ Harry Maier, "Heresy, Households, and the Disciplining of Diversity," in Late Ancient Christianity, vol. 2, A People's History of Christianity, ed. Virginia Burrus (Minneapolis: Fortress Press, 2005), 219.

${ }^{45}$ Did. 16.2 (tra. Michael W. Holmes). Taras Khomych, "The Admonition to assemble Together in Didache 16.2 Reappraised," VC 61 (2007), 121-141, argues that

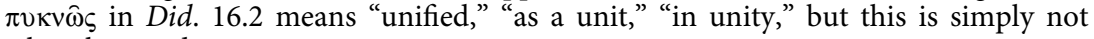
what the word means.

${ }_{46} 2$ Clem. 17.3 (tra. Michael W. Holmes).

47 Barn. 19.10. 
the existence, at least in one place, of a schedule of Christian meetings on every day of the week.

That Christians met more frequently than only on the Lord's day is also the impression one obtains from the Didache. Christian communities had to receive visiting apostles and prophets "as the Lord." 48 Yet, these visitors were not allowed to stay for more than one or two days, ${ }^{49}$ during which they were supposed to preach and teach in one or more of the community meetings. ${ }^{50}$ In these meetings, a meal could be served, although not at the instigation of the visiting apostle or prophet..$^{51}$ Since it is unthinkable that apostles and prophets arrived in a Christian community always on Saturday or Sunday, the conclusion is inescapable that the congregations the Didachist has in mind, held more gatherings a week than the standard eucharistic celebration on Sunday alone. ${ }^{52}$

Summarising, it may be stated that from the beginning of the second century at the latest, Christians began to have more than one meeting a week. In addition to their gathering on Sunday evening, they began to meet for worship at dawn. In this, they followed the example of many other religious groups in the Graeco-Roman world. This development was furthered by the fact that more and more local Church officials were supported by their congregation. This enabled them to organize and conduct more than one or two weekly gatherings on Sunday. The weekly gatherings at sunrise, first mentioned by Pliny as a feature of Christianity in Bithynia-Pontus, spread from the Sunday to all other days of the week. In the eyes of the Church officials, holding more gatherings a week was a means of strengthening the faith of the members of their congregations, as well as protecting them from slipping into religious negligence or "unorthodox" ideas.

\section{THE MORNING GATHERINGS IN THE SECOND AND THIRD CENTURIES}

The evidence for the history of the Christian morning gathering in the second and third centuries is scanty and hardly allows of a satisfactory

${ }^{48}$ Did. 11.4.

${ }^{49}$ Did. 11.5.

${ }^{50}$ Did. 11.7-12.

${ }^{51}$ Did. 11.9.

${ }^{52}$ Did. 14.1. 
reconstruction of that history. One should beware of perceiving it simply as a linear process. Basically, three changes took place: (1) the morning gathering spread from the Sunday to other mornings, and in certain cases to all mornings of the week; (2) the morning gatherings were extended to include a Eucharist, Scripture reading and a sermon; and (3) the Sunday evening gathering with its communal meal lost its importance in favour of the Sunday morning gathering. From the middle of the third century, the Sunday evening meal continued to exist as an agape, but the really significant gathering became that on Sunday morning, including the Eucharist. These changes did not occur everywhere at the same pace. Considerable allowance should be made for regional differences. This makes it difficult to describe the history of the Christian gathering in the second and third centuries as one continuous history. In this section therefore only the literary data that illustrate how the morning gatherings of Christians in the second and third centuries developed in different places and times will be presented and discussed.

In the second century, besides coming together on Sunday evening and Sunday morning, Christians began to gather also on other mornings of the week; morning services such as recorded by Pliny as taking place on Sundays also began to be held on other days of the week..$^{53}$ At first, these gatherings did not yet comprise a meal but with time they came to include a eucharistic meal, probably a simple, modest form of breakfast with bread and wine; this communal breakfast became the daily morning Eucharist. Obviously, certain Christians felt that one Eucharist a week, on Sunday evening, was not enough. Longing for the community with the Lord and their fellow Christians, they began to celebrate the Eucharist also on one or more mornings of the week. Tertullian makes it clear that in his time the Eucharist was celebrated early in the morning, not only on the Christian fast days, that is, on Wednesday and Friday but also on the other days of the week. ${ }^{54}$ For

${ }_{53}$ These services took place sometime early in the morning before work. The growing number of morning services, first without and then with the celebration of the Eucharist, mirrors the wish expressed by the author of the Did.: "Frequent the company of the saints daily, so as to be edified by their conversation" (4:2) and "Come often together for spiritual improvement" (16:2). For the third century, see Trad. ap. 35 and 39.

${ }^{54}$ Tert., Or. 19.1-4 (dated to 198-204 CE), states that certain Christians, who were willing to receive the Eucharist daily in morning services, refused to do so on fast days, Wednesday and Friday, because they did not want to break their fast. For "sta- 
second-century Christians, the eucharistic bread represented "the medicine of immortality" ( $\varphi \alpha ́ \rho \mu \alpha \kappa o v ~ \alpha \dot{\theta} \alpha v \alpha \sigma i \alpha \varsigma$ ), as Ignatius calls it. ${ }^{55}$ $\mathrm{He}$ also remarks that "unless one is within the place of sacrifice he is deprived of the bread of God." ${ }^{56}$ Such interpretations of the Eucharist make it understandable that Christians longed to partake of it more often and sometimes even saved the bread in order to take it home and eat it the following morning. ${ }^{57}$

The earliest reference to eucharistic celebrations at dawn probably occurs in Apuleius' Metamorphoses (ca. 150-170 CE). The main character of this novel, after having been changed into an ass, is bought by a baker in a Thessalian town. Apuleius portrays the baker's wife as an extremely malicious, immoral and perverse woman. Among other things, this is what he says about her:

She scorned and spurned all the gods in heaven, and, instead of holding a definite faith, she used the false sacrilegious presumption of a god, whom she would call "the only One", to invent meaningless rites to cheat everyone and deceive her wretched husband, having sold her body to drink from dawn and to debauchery the whole day. ${ }^{58}$

Most interpreters of this passage have regarded the baker's wife as Christian, whereas others have taken her to be Jewish or admit both possibilities. ${ }^{59}$ However, in Apuleius' biased description the woman not only calls her God "the only God" (unicus) but also participates in certain rites involving the consumption of wine, which enable her to become drunk from early in the morning. This is an indication that Apuleius is depicting her as a Christian, for, as stated above, there is indisputable evidence in Tertullian that some decades later the Eucharist was celebrated in the early morning of various or all weekdays. ${ }^{60}$ It

tio solvenda sit accepto corpore Domini," that is, "in receiving the body of the Lord they have to break the fast." This passage shows that in North-Africa about $200 \mathrm{CE}$ the Eucharist was celebrated early in the morning at least on Wednesday and Friday and probably on all days of the week. For further evidence for daily celebrations of the Eucharist, see below.

${ }^{55}$ Ign., Eph. 20.2.

${ }^{56}$ Ign., Eph. 5.2.

57 Tert., Or. 19.1-2; Ad ux. 2.5.

${ }^{58}$ Apul., Met. 9.14 (tra. J.A. Hanson, slightly adapted).

${ }^{59}$ For a useful discussion of this problem, see B.L. Hijmans (Jr.) et al., Apuleius Madaurensis. Metamorphoses. Book IX. Text, Introduction and Commentary (Groningen: Forsten, 1995), 380-382.

60 Tert., Cor. 3.3: "Eucharistiae sacramentum... etiam antelucanis coetibus...sumimus." From Tert., Or. 19 it is clear that certain members of a Christian congregation, 
may be relevant here to note that both Apuleius and Tertullian were active as rhetor in and near Carthage. Apuleius' allegation that the eucharistic meeting also gave the woman occasion for sexually immoral behaviour may be seen as a confirmation that he is portraying her as a Christian. The accusation that Christians at their common meals gave themselves over to sexual misconduct was a standard element in second-century pagan anti-Christian propaganda. ${ }^{61}$ Consequently, there are good reasons to assume that the passage under consideration is the earliest witness for eucharistic celebrations in the morning.

Historians of the Christian liturgy have thought for a long time that the Sunday gatherings of Christians described by Justin also took place in the morning. ${ }^{62}$ Other scholars have stated that Justin says nothing with regard to the hour of the day at which his Eucharist took place and that, as a result, it cannot be ascertained whether it took place in the morning or in the evening: it could be either. ${ }^{63}$ However, some elements in Justin's account of the meetings at issue seem to suggest that they took place on Sunday evening rather than on Sunday morning. First, Justin observes that deacons brought what remained of the meal to the orphans, the widows, the sick, the needy, the prisoners and travellers passing through. ${ }^{64}$ This suggests that what was distributed consisted of substantial portions sufficient to feed people, and that the meal itself was not a small or symbolic, but a sizable meal, that is, a supper. ${ }^{65}$ Second, the meeting described by Justin comprised so many

who wanted to fast on Wednesday and Friday, refused to receive the Eucharist in the morning gathering in order not to break their fast. However, the passage makes it clear that on Wednesday and Friday morning the Eucharist was celebrated and distributed. According to Tert., Idol. 7 there were Christians who "mangled His body daily"; in the context, "daily" must mean every morning.

${ }_{61}$ See, e.g., Just., 1 Apol. 26.7; Athenag., Plea 3; 31; Tert., Apol. 7.2; and Min. Fel., Oct. 9.7; 28.3, 5; 31.1 .

${ }_{62}$ E.g., Hans Lietzmann, Mass and Lord's Supper (Leiden: Brill, 1979; originally Messe und Herrenmahl, Bonn: Marcus and Weber, 1926), 211.

${ }_{63}$ Paul Bradshaw, Eucharistic Origins, 69. See also Maxwell E. Johnson, "The Apostolic Tradition," in The Oxford History of Christian Worship, eds. Geoffrey Wainwright and Karen B. Westerfield Tucker (Oxford: Oxford University Press, 2006), 50.

${ }^{64}$ Just., 1 Apol. 67.6.

${ }^{65}$ That the so-called apophoreta were substantial, not only symbolic, small portions of food, is clear from Trad. ap. 28, where it is supposed that all participants in the Lord's Supper eat their fill, not only those present but also those to whom the apophoreta are brought. It also appears from Trad. ap. 24 where those who have to bring the apophoreta to widows and sick are admonished to bring it the same day, that is, the same evening, not the next day, since the recipients are poor people who need the food for their nourishment. 
activities that it is difficult to imagine that all these took place early in the morning before the participants went to their work. Finally, the reason why Justin does not mention the hour at which his Sunday meeting was held may be precisely because he wanted to avoid revealing that it was an evening meeting. After all, he is writing here an apologia in defence of the Christians; it was safer not to present the Christian meetings here as the evening meeting of an association, for such evening meetings could easily be suspected of being a breeding place of political subversivity. It was against such evening meetings that Pliny had taken his measures in Bithynia-Pontus. All in all, the Sunday gathering described by Justin is likely to have taken place in the evening, not in the morning.

The first author to attest explicitly the daily celebration of the Eucharist in the morning is Clement of Alexandria in his Quis dives salvetur. Here Clement introduces Christ as saying: "I am your nurse, giving myself for bread, which none who taste have any longer trial of death,

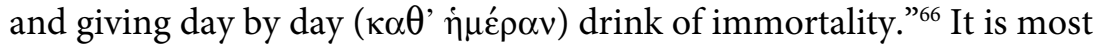
likely that these celebrations took place in morning gatherings, for in the first three centuries of Christianity we never hear of eucharistic celebrations being held on every evening of the week. ${ }^{67}$ Elsewhere, Clement goes into a consideration of the time during which Christian married couples could or should not engage in sexual intercourse. He observes that they must certainly not do this "after coming home from church, or from the market, early in the morning in the way of a cock," but in the evening after supper. ${ }^{68}$ Clement here conceives of the Christian gathering as taking place early in the morning on several or all days of the week. The same conclusion can be drawn from a passage in his Paedagogus in which he criticizes Christians who, on random days of the week, participate in the Christian gathering in the morning but give themselves over to worldly amusement in the evening:

After having paid reverence to the discourse about God, they leave within the church what they have heard. And outside they foolishly amuse themselves with impious playing, and amatory quavering, occupied with flute-playing, and dancing, and intoxication, and all kinds of trash. They who sing thus, and sing in response, are those who before hymned

${ }^{66}$ Clem. Al., Q.d.s. 23 (tra. G.W. Butterworth).

${ }^{67}$ Acta Petri 13, where the Roman church is said to meet "day and night" with their presbyter (see below), cannot be used as evidence to the contrary.

${ }^{68}$ Clem. Al., Paed. 2.96. 
immortality,-found at last wicked and wickedly singing this most pernicious palinode, "Let us eat and drink, for tomorrow we die."

The implication of this passage is that Christians went to church in the morning on several days of the week and could perhaps do so every day.

At the end of the second century, the custom of Christians to meet daily is also the supposition of the Acts of Peter (180-200 CE). According to this work, the Christians of Rome "met day and night in the house of Narcissus the presbyter." 70 This passage may give an exaggerated image of the religious zeal of the Christian community in Rome but the mention of daily gatherings, also referred to in other passages of these Acts, probably does reflect the situation in the author's church at the end of the second century.

Tertullian, in several of his works, takes it for granted that Christians meet every day of the week before dawn to celebrate the Eucharist. ${ }^{71}$ Recently, some scholars have argued that the rite in these morning assemblies was not the celebration of the Eucharist, but just the distribution of bread, sanctified during the supper (or agape) of a preceding evening, and not eaten until the end of the fast. ${ }^{72}$ However, this is an unlikely interpretation of the evidence in Tertullian. First, in De

${ }^{69}$ Clem. Al., Paed. 3.80 .4 (tra. B.P. Prattein in ANF). It is true that this passage does not mention the Eucharist but the daily celebration of the Eucharist is clearly referred to in Clem. Al., Q.d.s. 23, quoted above.

${ }^{70}$ Acta Petri 13 (tra. J.K. Elliott, p. 409). Cf. Acta Petri 7; 20; 29; 30; 31.

${ }^{71}$ Tert., Or. 19; the refusal of certain Christians to partake of the Eucharist on fast days implies that it was celebrated at least on Wednesday and Friday. Idol. 7.1-3: "quotidie corpus eius lacessunt." The daily celebration of the Eucharist mentioned here must have taken place at dawn, for it is unimaginable that people would gather for a communal meal every evening. See also Apol. 7.4: "Quotidie obsidemur, quotidie prodimur, in ipsis etiam plurimum coetibus et congregationibus nostris opprimimur." Cf. Nat. 1.7. Some authors have argued that these passages may indicate that in Tertullian's time a daily service for prayer but not a Eucharist was held; they assume that eucharistic celebrations were held only on Sunday, Wednesday and Friday. People could take the bread from these celebrations home and eat it on other days and, thus, eat Christ's body daily even when there was no Eucharist. See, e.g., P.G. van der Nat, Quinti Septimi Florentis Tertulliani de Idololatria (Leiden: Saint Lucas Society, 1960), 93-94. However, the context of Idol. 7.1-3 clearly speaks about various activities taking place in church and within the eucharistic gathering, not at home, so the "lacessere" (assailing, stirring, moving) of Christ's body must also be something taking place in the gathering. Moreover, a daily Eucharist with consumption of the elements is the practice known to Traditio apostolica (chs. 22;35-37). There is little reason, therefore, to try to deny the same situation for Tertullian.

${ }_{72}$ Andrew McGowan, "Rethinking Agape and Eucharist in Early North African Christianity," 167-172; P. Bradshaw, Eucharistic Origins, 99-103; recently followed 
corona 3.3 Tertullian means to say that the Eucharist, which Jesus had ordered to celebrate at suppertime, was celebrated by the Christians of his time in meetings before daybreak. In this context Tertullian speaks of the celebration of the Eucharist as "Eucharistiae sacramentum... sumimus." Here "sumimus" does not mean that the participants only received the bread and the wine without consuming them; it means that they consumed them at a time not indicated by Jesus. Secondly, it is true that, according to De oratione 19 , some believers refused to attend the morning assembly on fast days because they did not wish to break their fast. However, Tertullian points out that receiving the body of the Lord does not break the fast. From this it is clear that the gatherings on fast days comprised a Eucharist with the consumption of the eucharistic elements. Moreover, those who refused to come were only a small group out of the number of those who participated normally in the Eucharist on those days.

An account of a morning gathering with Eucharist occurs in the Acts of Thomas (Syria, third century?). ${ }^{73}$ The gathering described takes place at dawn and consists of prayer, an admonition by the apostle and a eucharistic meal. The Acts of Thomas reflect a situation in which meetings of Christians were held in the morning on several days of the week (chapters 27-29).

The Apostolic Tradition records morning services on all days of the week (including Sundays), before working hours. ${ }^{74}$ These services included the reading of Scripture, an instruction, the exchange of the kiss of peace, prayer, and the Eucharist. Catechumens were not allowed to practise the holy kiss, ${ }^{75}$ nor of course to participate in the Eucharist. Before the Eucharist, the officiant prayed for them with imposition of hands and then dismissed them. ${ }^{76}$ The Traditio apostolica allows for the possibility that at places, due to the lack of competent clergy, the morning gatherings could not be held every day. Wherever this

by G. Rouwhorst, "The Roots of the Early Christian Eucharist: Jewish Blessings or Hellenistic Symposia?” 298-299.

${ }^{73}$ Acta Thom. 29 (J.K. Elliott, p. 459). In this case the gathering at daybreak took place on Sunday. For a similar gathering with Eucharist at dawn but on another day than Sunday, see ch. 27.

${ }^{74}$ Trad. ap. $22 ; 35+36+37$. From ch. 25 "He [the bishop] should not say "sursum corda," for that is said in the morning Eucharist ['ंv $\alpha \varphi \rho \rho \alpha$, oblatio]," it can be gathered that a Eucharist at dawn took place on Sunday morning, in addition to the Sunday evening meeting, that is the charitable кvpıккòv $\delta \varepsilon i \pi v o v$ (= the eulogia, chs. 25-28).

75 Trad. ap. 18.

76 Trad. ap. 19; 37. 
was the case, the faithful should begin the day by praying and reading "a holy book" in private. ${ }^{77}$ However, in principle "the deacons and presbyters should come together every day at the place appointed by the bishop, unless sickness prevents them from coming," teach those who have come to church. Apparently, it was obligatory for the clergy to be available on a daily basis at these morning gatherings so that lay persons could come to church on any particular morning and receive instruction.

In the third century, morning gatherings on weekdays are attested not only for North-Africa and Rome but also for Syria and Palestine. In Syria, morning gatherings are mentioned by the Didascalia. ${ }^{79}$ In Palestine it is Origen who speaks about meetings taking place on several successive days of the week: in his sermons he repeatedly points out that the Scripture reading of the day is the continuation of the reading of the previous day. ${ }^{80}$

An important change in the history of the Christian gathering took place by the middle of the third century. Traditionally, the gathering on Sunday evening had been regarded as the main weekly event in the Christian community, also after a eucharistic celebration had been added on Sunday morning and other mornings of the week. By the middle of the third century, the Eucharist on Sunday evening proves to lose much of its significance in favour of the Eucharist on Sunday morning. This development is documented by the Traditio apostolica and Cyprian.

Cyprian is familiar with weekly communal meals on Sunday evening as well as eucharistic gatherings, including the reading of Scripture, on every morning during the week. ${ }^{81}$ In one passage he mentions, next to the traditional gathering on Sunday evening, the daily celebration of the sacrament in the morning.

But for us, beloved brethren, besides the hours of prayer observed of old, both the times and the sacraments have now increased in number. For

77 Trad. ap. 35; 41.

78 Trad. ap. 39.

79 Did. ap. 2.27-28, 58-59, 61; cf. 6.22 .

80 Or., Hom. Gen. 10.3; Hom. Jos. 4.1. It has been suggested that according to Or., C. Cels. 8.22, the Christian gathering on station day was on Friday evening. See P. Nautin, Origène. Sa vie et son oeuvre (Paris: Beauchesne, 1972), 391. However, there is nothing in the text to substantiate this view.

${ }^{81}$ Cypr., Or. Dom. 18; Op. eleem. 15; Ep. 29.1.1; 39.4.1; 57.3; 58.1. 
we must also pray in the morning, that the Lord's resurrection may be celebrated by morning prayer. ${ }^{82}$

However, in his famous Epistle 63, where he deals with the problem of some people using water at the Eucharist in the morning and wine only at the eucharistic celebration in the evening, he gives the morning ceremony much greater significance than that of the evening. The reason he gives for this appreciation is that the Christian community could not participate as a whole in the communal supper; and if not all members could participate, the supper was not the "sacrament." Obviously, all members could participate in the Eucharist on Sunday morning but not in the supper on Sunday evening. Why this was so remains a matter for conjecture. One possibility is that, if the supper was still a real, full meal, the members of the community were too numerous logistically to allow them all to participate in the supper. The Eucharist in the morning is likely to have been a much simpler sort of meal than the supper. Another possibility is that the supper had taken the character of a charity meal for the poorer members of the community and that the more well-to-do Church members disdained making use of this social service or mingling with those who did make use of it. However, according to Cyprian, it may be that not all Church members could attend the supper, although they could attend the Eucharist in the morning. That is the reason why he did not consider the supper any longer as the eucharistic sacrament: that function was now ascribed only to the Eucharist in the morning.

When we dine we cannot call all the people together to share in our meal; we cannot celebrate the full truth of this sacrament if we do not have all of the brethren present.... Whereas for us we celebrate the resurrection of the Lord in the morning. ${ }^{83}$

Thus, according to Cyprian, the most important meeting on Sunday was the one held in the morning, whereas the evening meeting continued to exist as an agape meal whilst losing its function as a sacrament.

The same development can be observed in the Traditio apostolica. The chapters 25-28 give detailed instructions for the celebration of a ceremony which takes place in the evening and consists, inter alia, of

82 Cypr., Or. Dom. 35 (tra. Ernest Wallis in ANF).

${ }^{83}$ Cypr., Ep. 63.16.1-2 (tra. G.W. Clarke). 
a prayer of thanksgiving, recitation of psalms by children, a deacon and the bishop, a benediction over the cup of wine, the distribution of bread, drinking and eating. What one eats and drinks is a full, substantial meal, not the ritual consumption of small symbolic portions of food and drink. The participants are invited to eat their fill but are warned to eat and drink decently and with moderation and not to become drunk. ${ }^{84}$ The meal is called "the Supper of the Lord" ( $\delta \varepsilon i \pi v o v$

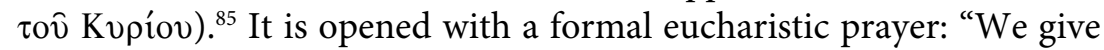
thanks to thee, Lord, through your Son Jesus Christ, our Lord, through whom you have illuminated us by revealing to us the incorruptible light, etcetera." 86 This meal is the traditional Lord's Supper held on Sunday evening. However, the description of this communal meal contains several hints that, according to the author of the Traditio apostolica, this meal was of less significance than the Eucharist celebrated in the morning. At the beginning of the ceremony, for instance, the bishop must not say "Lift up your hearts"; the reason is that "this is said during the oblation," that is, during the Eucharist in the morning. Furthermore, when the eating begins, the participants should take first a piece of bread from the hand of the bishop and then break their own bread, for this meal "is a benediction ( $\varepsilon \dot{\lambda} \lambda \mathrm{\gamma} \gamma i \alpha)$, not a Eucharist

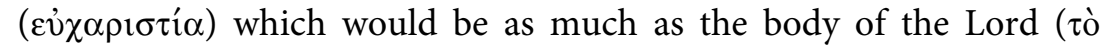

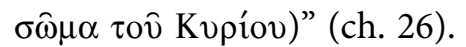

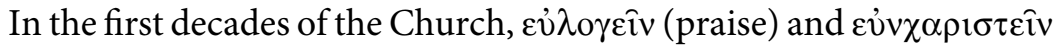
(say grace) had practically been synonyms ${ }^{87}$ as well as when they were used for the saying of grace over food or drink. ${ }^{88}$ Now all of a sudden

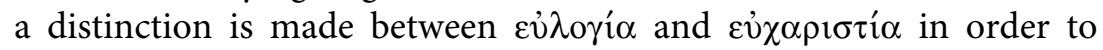
reduce the significance of the Lord's Supper being celebrated in the evening, in comparison with the Eucharist celebrated in the morning. It is even claimed that at the Lord's Supper one does not eat the body of the Lord, with the implication that the body of Christ is eaten only during the morning Eucharist.

Everything indicates that the evening meal served to allow poorer members of the congregation to eat a good meal at least once a week. This may explain why the whole section on this supper is concluded

\footnotetext{
84 Trad. ap. 28.

85 Trad. ap. 27.

86 Trad. ap. 27.

87 See, e.g., 1 Cor. 14:16, where these verbs are used side by side.

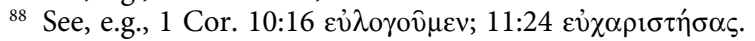


with warnings to the effect that the participants in this meal should behave decently. They should not become drunk, turn themselves into an object of derision, nor should they finish all the food; rather they should leave some for those absent. Further instructions were that they should not quarrel, speak unless the bishop asks something, and keep silent when the bishop speaks. One gains the impression that the author of this passage has a low opinion of the participants' table manners as they consumed the supper on Sunday. In his view, this supper was a charity meal, but no longer the sacramental meal of the community.

Here one witnesses how the Lord's Supper on Sunday evening loses its function as the congregation's sacramental meal in favour of the Eucharist celebrated on Sunday morning. It is the same process as we observed in Cyprian. The Sunday evening meal retained the character of charity institution or welfare provision. This charity supper, for which the name agape was reserved from now on, continued to exist for centuries. ${ }^{89}$ By the year $400 \mathrm{CE}$, Augustine describes it as a selfevident reality. ${ }^{90}$ It is still mentioned by the Trullan Synod of $692 .{ }^{91}$

\section{Conclusions}

At the beginning of the second century at the latest, Christians began to hold services of prayer and singing on Sunday morning before work. These morning services took place next to the eucharistic gatherings on Sunday evening. The morning gathering formed the Christian counterpart of the meetings for prayer and worship which were held by many other religious groups in the Graeco-Roman world, including pagan and Jewish worshippers.

In the course of the second century, such morning services, mainly consisting of prayer and singing, spread over the other days of the week, possibly first the fast days, Wednesday and Friday, and later all other days of the week. Later in the second century, the morning gatherings were enlarged to include a sober form of Eucharist,

${ }^{89}$ For the later history of the agape, see W.-D. Hauschild, "Agapen I," in Theologische Realenzyklopädie, vol. 1 (Berlin: De Gruyter, 1977), 748-753, esp. 752.

${ }^{90}$ Augustine, Contra Faustum 20.20: "Our agapai nourish the poor."

${ }_{91}$ Concilium quinisextum, canon 74, containing a prohibition of agape celebrations in Church buildings. 
the reading of Scripture and a sermon or instruction. As a result, the morning gathering of Christians in the third century contained the reading of Scripture, a sermon or instruction, prayer, and the celebration of the Eucharist. On Sunday, this gathering was held in addition to the meeting in the evening, in which the traditional Lord's Supper was celebrated as a full meal.

However, from about 230 onwards, the Lord's Supper began to lose its function as the main ritual of the Christian community, whereas the Sunday morning meeting gained in significance, mainly because many more people attended the morning Eucharist than the evening meal. The latter became a charity meal for the less well-off members of the congregation. Thus, the Sunday evening meal was reduced to a form of Christian welfare, the agape meal, whereas the Sunday morning gathering with its simpler form of Eucharist became the central ritual of the Church.

Originally, the Lord's Supper and the agape had been one and the same eucharistic meal, celebrated on Sunday evening. In the third century the Lord's Supper became a charity meal, for which the term agape came to be reserved. The Sunday morning Eucharist became the more important of the two rituals and as a result the Lord's Supper held in the evening gradually lost its sacramental character. 